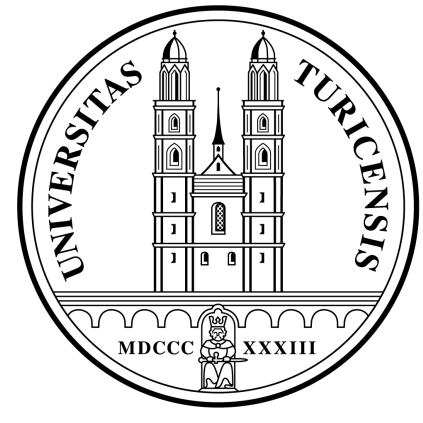

Institute for Empirical Research in Economics

University of Zurich

Working Paper Series

ISSN 1424-0459

Working Paper No. 158

INEQUALITY AND ECONOMIC GROWTH

EUROPEAN VERSUS U.S. EXPERIENCES

Reto Foellmi and Josef Zweimüller

June 2003 


\title{
INEQUALITY AND ECONOMIC GROWTH EUROPEAN VERSUS U.S. EXPERIENCES
}

31. Volkswirtschaftliche Tagung der OeNB 2003

\author{
RETO FOELLMI \\ Universität Zürich \\ JOSEF ZWEIMÜLLER \\ Universität Zürich, CEPR, CESifo, and IZA ${ }^{*}$
}

June 2003

\begin{abstract}
This paper discusses long-term trends in the macroeconomic growth performance and in income distribution in Europe and the U.S. We review insights from the recent macroeconomic literature on inequality and growth and use these insights to shed light on the growth and inequality trends.
\end{abstract}

\footnotetext{
${ }^{*}$ We thank Josef Falkinger and Manuel Oechslin for helpful comments.
} 


\section{Introduction}

The goal of this paper is to discuss differences and similarities of European countries and the United States with respect to income distribution and the macroeconomic growth performance. Our aim is twofold. First, we discuss recent insights from the macroeconomic literature on the impact of inequality on the macroeconomic growth performance. Second, an attempt is made to use these insights to shed light on recent European and U.S. experiences.

Our focus differs from the recent literature in two important respects. First, the recent literature has extensively studied the sources of changes in inequality. Instead, our paper turns this question upside down. Rather than looking at the explanations of high and rising inequalities, we are posing the question: Are there any feedback effects from high and increasing inequalities on the long-run growth process?

In contrast, our paper is concerned with the consequences rather than the causes of inequality, so we will look at mechanisms by which income and wealth inequality is transmitted to growth outcomes. While, in principle, there may be many such channels, two of them seem particularly relevant in the context of recent European and U.S. macroeconomic experiences: (i) the effects of inequality on human capital accumulation and (ii) the impact of inequality on innovation incentives and price setting behavior.

Imperfections on the capital market are a fundamental problem inherently associated with educational choices. By the very nature of educational investments no collateral can be offered and the investment returns typically accrue to children who are not legally bound to honor the debts of their parents. Clearly, how many individuals will be constrained in their educational choices will depend on the income distribution. Many recent theories suggest that human capital investments are an important determinant of long run growth rates.

Effects of income distribution transmitted via imperfections in the product market are important to understand the incentives to innovate. The income distribution is relevant in this respect because the demand for innovators' products crucially depends on the income distribution when the poor do not consume the same goods as the rich. More generally, the fact that market demand functions are affected by inequality is most obvious in Engel's law according to which the budget share for food decreases in income. According to this 
empirical observation, income distribution must play a central role both for the market size and price setting behavior of monopolistic firms. ${ }^{1}$ Hence income distribution also affects the prices and the profits of innovative firms. As innovations are a crucial determinant of productivity growth, we can ask how inequality affects growth-outcomes.

Recent empirical evidence suggests, perhaps unsurprisingly, that inequality is higher in the U.S. than in almost all European countries. While inequality has been increasing strongly in some European countries (in particular, in the U.K.), recent empirical evidence suggests that the increase might have been strongest in the U.S., in particular if one takes a closer look a the top incomes.

If inequality in Europe is smaller and has been increasing less strongly than in the U.S., what are possible implications for relative macroeconomic outcomes? The experience in the very recent past suggests the U.S. have done (relatively) better than most European countries. Hence, we might be lead to conclude that inequality is a (perhaps) unpleasant but necessary precondition for favorable macroeconomic performances. In fact, the existence of such a trade-off between equity and efficiency was a dominant proposition that has been held by the majority of the economics profession.

The more recent macroeconomic literature, however, has challenged this view both on theoretical and on empirical grounds. First, the trade-off has been questioned as a matter of fact. There is very little empirical evidence suggesting that higher inequality is favorable for the long-run growth experience of an economy. Cross-country data suggest that economies with low initial inequality have grown much faster in subsequent decades than highinequality countries. The second challenge for the equity-efficiency trade-off view comes from the theoretical side. While neoclassical macroeconomics has focused on perfect markets, market imperfections are central in more recent theories. When markets imperfections are accounted for, income inequality becomes an important determinant of macroeconomic outcomes. In fact, in such an imperfect world, it may well be that lowinequality countries have an advantage in the long-run, as the inefficiencies that result from market imperfections will be less severe when incomes are more evenly distributed.

\footnotetext{
${ }^{1}$ Technically speaking, income distribution plays a role for market demand curves if consumers have nonhomothetic preferences.
} 
The paper is organized as follows. We will start with a review of some empirical facts. In Section 2 we discuss differences in income inequality between Europe and the U.S. and look at recent trends. We will see that the available evidence supports the view that in the U.S. incomes are less evenly distributed than in European countries, and perhaps less unevenly than in Europe as a whole. Moreover, this recent evidence suggests that U.S. top incomes have been increasing dramatically which may be due to the decline in progressive taxation. It is likely that this may foster further the trend towards more inequality in the future.

In Section 3 we contrast these inequality trends to the differences in macroeconomic outcomes on the two sides of the Atlantic. We start by reviewing the recent and more longterm EU and U.S. growth experiences. Perhaps interestingly, and certainly at odds with much of the recent public debate, European countries have clearly outperformed the U.S. over the longer run in terms of productivity growth.

Section 4 briefly reviews the recent macroeconomic literature on long-run growth and income distribution and discusses some theoretical approaches that have put forth to explain the evidence. The following sections deal in more detail with potential effects of income inequality on human capital accumulation under capital market imperfections (Section 5) and with the impact of income inequality on innovation incentives and price-setting behavior when there is imperfect competition on product markets (Section 6).

Section 7 summarizes.

\section{Differences and trends in income inequality: U.S. versus Europe}

In this section we take a look at the empirical evidence on income distribution in the U.S. and in Europe. Table 1 shows a recent cross-country comparison among the OECD countries based on data from the Luxembourg income studies, the most reliable and informative database for cross-country comparisons. Table 1 shows various interesting indicators. One such indicator is the Gini coefficient. Comparing this measure across countries confirms expectations: income inequality in the U.S. is much higher than in any other country listed in Table 1. For instance, the Gini coefficient is 0.37 for the U.S., 0.30 for Germany, and only around 0.23 for a typical Nordic country. 
A further interesting inequality indicator is the $90 / 10$ percentile ratio, which is a rough measure of the range between the poorest and the richest in a society. For instance, this ratio is 6.4 in the U.S., about 3.8 in Germany, and around 2.8 in a typical Nordic country. The bars in the middle of Table 1 show this range graphically. The bars show that, relative to the median within each country, in the U.S., the poor are poorer and the rich are richer than in any other country listed in Table 1.

\section{Table 1: Income Inequality in Industrialized Countries}

Note that Table 1 may give a biased picture about differences in income inequality between "Europe" and the U.S. The U.S. encompass different states with rather different per-capita income levels that are lumped together. Europe also consists of different countries, but these are treated as separate entities in Table 1. In particular, inequality within Europe as a whole may be higher once we account for cross-country differences in per-capita incomes. Atkinson (1995) made an attempt to estimate the level of inequality of the Europe-wide distribution of income. Table 2 reports the numbers.

\section{Table 2: "Europe-wide" and U.S. Distributions}

The set of countries that is included to make these calculations is somewhat selective and driven by data availability. But it includes poor countries such as Portugal as well as rich countries such as Switzerland and Luxembourg, hence the numbers should come close to the measure we are interested in. Table 2 shows that taking account of cross-country income differences within Europe does not change the general picture. The U.S. still has the more unequal distribution of income. Two points are worth mentioning here. First, the numbers are from the mid and late 1980s and probably underestimate the actual differences. This is mainly because there has been convergence across countries within Europe, whereas the distribution of per capita income across U.S. states has been more stable. Second, the picture may be different once we consider also Eastern Europe as these countries consist of large populations with low per capita-incomes.

What are the trends in the distribution of income and what are the differences and similarities between Europe and the U.S. along this dimension? Is the general perception of a widening 
in the distribution of income actually visible in the data? Again, the cross-country data lag behind and the numbers we present refer to changes in inequality between the late 1970s and the mid 1990s (Figure 1).

\section{Figure 1: Trends in Disposable Income Inequality}

Figure 1 shows that rising income inequality is a rather common phenomenon. Interestingly, a first look at the data suggests that the countries that experienced the highest increase in income inequality are European countries. In the U.K., for instance, the Gini coefficient has grown by 8 points from 0.27 in 1979 to 0.34 in 1995 (an increase in measured inequality of almost one third!). Inequality has also been strongly increasing in the Netherlands and in Sweden, albeit both countries (in particular Sweden) started out from a rather low level of inequality. The remaining European countries listed in Figure 1, Switzerland, Germany, Norway, experienced a modest increase, whereas in Finland, Ireland, and Italy there was even a reduction in inequality.

Evidently, there are pronounced differences in distributional outcomes across European countries. In particular, there is not a very clear trend towards increased inequality. In contrast, the U.S. clearly experienced an increase in inequality. This increase is modest if compared to the one that took place in the U.K. but is of about equal size as the one of the Netherlands. In particular, the increase in U.S. inequality is higher than in Germany, France, and of course, Italy (which experienced a decline in inequality).

Note, however, that there are good reasons to believe that the increase in inequality in the U.S. may be strongly underestimated. Recent evidence by Piketty and Saez (2003) suggests that top incomes in the U.S. have increased substantially during the last 25 years, whereas such a development did not take place in Europe. Survey data like the Luxembourg income studies do not adequately sample the very high incomes (which make up a large fraction of total income). Hence when the income share of the top incomes changes, such survey measures will understate the real changes in inequality.

In fact, the increase in top incomes in the U.S. has been dramatic. In the late 1970s, the richest $1 \%$ in the U.S. earned about $8 \%$ of the national income - a number that compared well to the situation in France (Piketty, 2003). By the end of the 1990s, as much as $14.6 \%$ of 
total U.S. incomes was concentrated in the hands of the top $1 \%$. In contrast, in France the share remained between 7 and 8 percent throughout the 1980s and 1990s. Piketty and Saez (2003) show also numbers for the U.K. that underline that the U.S. experience was extraordinary: In the U.K. top incomes increased slightly but still remained at levels that are close to the French numbers. The U.S. picture is even more dramatic if we look at top $0.1 \%$ and the top $0.01 \%$ incomes. The share of the former was $6 \%$ (3 times as high as in the $1970 \mathrm{~s}$ ) in 1998 and the share of the latter group was $2.6 \%$ of total U.S. income (5 times as high as in the 1970s). Piketty and Saez (2003) suggest that this is primarily caused by strong increases in top wage incomes. In addition, the decline in progressive taxation since the early 1980s may have contributed to the increase.

Figure 2: Top $1 \%$ Income Shares 1960-1998, France and the U.S.

To get a sense of these numbers, let us make a simple calculation. The U.S. as a whole produce about $22 \%$ of the world production (measured in purchasing power parities (PPP); World Development Report 2003). This means that the U.S. top $1 \%$ earn about $3.1 \%$ of total world income. Compare this to the aggregate income earned by the total population on the African continent (Northern plus Sub-Saharian Africa). Measured in PPP terms, the total African production amounts to about $3.6 \%$ of world production. In other words, the richest 1 $\%$ in the U.S. can purchase almost as many good as the total African population and about 30 $\%$ more than the Sub-Saharian population. Clearly, the increase in the U.S. top income share is dramatic and sizeable even when viewed from a global perspective.

In sum, our look at the data suggests that:

(i) Inequality in most European countries is considerably smaller than in the U.S.

(ii) Inequality in (Western) Europe as a whole is probably smaller than in the U.S.

(iii) Inequality has increased more strongly in the U.S. than in Europe over the last two decades.

(iv) There has been a dramatic increase in U.S. top incomes. No such increase took place in Europe.

Observations (i) to (iii) are based on survey data, which underestimate distributional changes resulting from a higher concentration among the top incomes. Taking this into account the 
differences stated in (i) to (iii) above should be more pronounced than suggested by the survey data.

\section{Macroeconomic performance: Stagnating Europe and dynamic U.S.?}

In the last Section we have seen that Europe and the U.S. are quite different in terms of inequality. How about their relative growth performance?

Much of the recent economic policy debate is about why Europe is lagging behind the U.S. in terms of economic growth. In fact, a first look at the data suggests that recently the U.S. did much better than the European countries. The growth rate of real GDP between 1992 and 2000 was $3.7 \%$ in the U.S. but only $2.1 \%$ in the EU-15 (Blanchard, 2003). The picture seems to be confirmed when we look at long-term growth rates. The average growth of real GDP between 1960 and 2000 was $3.5 \%$ in the U.S. and only $3.1 \%$ in the EU-15. Can we conclude that both the recent and as well as the long-term growth performance of the U.S. economy dominated the one of Europe?

Clearly, to answer this question, it does not suffice to look at growth rates of aggregate income, but we have to consider growth rates of per-capita incomes (if we are interested in the standard of living of the average individual) or at growth rates of output per hours worked (if we are interested in the productivity of the average worker). In a recent and widely recognized paper, Gordon (2002) shows how these variables evolved over the very long term. To compare the growth performance of Europe and the U.S. the productivity growth is the variable of primary interest, so we will focus on the long-term changes in output per hours worked. Figure 3 shows the increase in this variable for both Europe and the U.S. over the past 150 years. Gordon's numbers suggest that the U.S. were leading Europe already in the second half of the $19^{\text {th }}$ century, and that this gap continuously widened until World War II (WWII). Since then, however, GDP per hours worked has grown much faster in Europe. Between 1950 and 1973, the annual productivity growth rate in Europe was 1,8 \% higher the one in the U.S. And even in the more recent past, between 1973 and 2000, 
productivity growth rates in Europe were by more than $1 \%$ larger than the ones in the U.S. As a result, labor productivity in Europe has reached U.S. levels by the mid 1990s. ${ }^{2}$

Figure 3 Real GDP per hour: Europe and U.S. 1870-2000

This evidence seems to be in stark contrast to the perceptions by the public. This is also noted in a recent comment in the "Economist" (Economics Focus, February $8^{\text {th }} 2003$ ):

"America's much trumpeted productivity miracle in the late 1990s created the misleading impression that Europe significantly lags America in the productivity league. It is true that, since 1995, American GDP per hours worked has risen by an annual average of $1.9 \%$, compared with only $1.3 \%$ in the European Union. However, over any longer period, up to half a century, Europe's productivity growth has outpaced America's."

While US-European differences in productivity per working hour have disappeared by the end of the $20^{\text {th }}$ century, significant differences in incomes per capita remain. According to Gordon (2002), U.S. per capita incomes diverged already from 1820 on and the highest difference was reached after the WWII. Since then there is convergence, but still the European incomes per capita have reached only $77 \%$ of U.S. levels today.

Given identical hourly productivities, any differences in incomes per-capita are, by definition, due to differences in hours worked per-capita. These differences can be explained by the following observations: (i) labor force participation is much lower in Europe than in the U.S. (which partly reflects the demographic structure of the population); the average European worker (ii) has a shorter working week; (iii) takes more vacation; and (iv) enjoys more work-free holidays. Parts of these different outcomes are due to workers' voluntary choices. Once we attach a monetary value to these kinds of leisure, a substantial part of the difference in per capita income between Europe and the U.S. will disappear.

\section{Inequality and Growth: evidence and some explanations}

The long-term record in terms of income inequality and long-term productivity growth of Europe and the U.S. is very clear: Europe had lower income inequality and a better long-term

${ }^{2}$ In fact, numbers presented in Gordon (2002, p.39) suggest that productivity levels in the year 2000, compared to the U.S. were $6 \%$ higher in Belgium, $4 \%$ higher in France, and $2 \%$ higher in the Netherlands. The German productivity level is at roughly the same level as the one of the U.S.. 
productivity growth record than the U.S. In other words, lower income inequality seems to go hand in hand with larger productivity progress. Can we argue, more generally, that inequality is beneficial for (productivity) growth? What does the recent macroeconomic literature have to say about the relationship between these two variables?

Recent theories as well as cross country evidence suggested that a more even income distribution may be an important determinant of long-term growth rates. ${ }^{3}$ Persson and Tabellini (1994) and Alesina and Rodrik (1994) presented empirical evidence that, both in a cross-section of countries and in long time series, high levels of initial inequality are associated with low subsequent long-run growth rates. Recent evidence by Engermann and Sokoloff (2002) compares inequality in Northern and Southern America and impressively demonstrates the strong and long-lasting effects of inequality on long-run economic development of Northern and Southern American economies. The empirical literature based on cross-country regressions clearly suggests that initial income and wealth inequality has a significantly negative impact on long-run growth rates. The view of the World Bank (stated on the webpage of the World Bank Network of Inequality, Poverty and Socio-economic Performance) is

“... while initial income inequality may not directly affect an economy's aggregate growth potential, other things being equal, it does proxy for more fundamental inequalities of wealth. Once measures for those are included, there seems to be a significant negative relationship between asset inequality and growth."

What do recent economic theories tell us about the relationship between income inequality and the macroeconomic growth performance of economies? Persson and Tabellini (1994) suggest the following explanation. High inequality in pre-tax incomes leads the majority of people to support redistribution by means of a progressive tax system. Inequality is bad for growth, because such taxation is detrimental to investment incentives.

The available empirical evidence, however, does not support the above model. First, in crosscountry data there is no statistically significant impact of inequality on taxes and transfers. Secondly, there is very little evidence that redistribution has a detrimental impact on investment and growth. Whether or not higher taxes have an impact on growth and investment depends on how the tax revenues are spent: The transfer/GDP ratio and the fraction of public

\footnotetext{
${ }^{3}$ See Falkinger (1997) for a stimulating discussion of many arguments that were put forth in the literature.
} 
expenditures on education frequently have a positive and statistically significant impact on growth.

There are further plausible reasons for a negative inequality-growth relationship that are more consistent with the evidence. One such explanation is that inequality, if not mitigated by public redistribution measures, leads to political instability, which has a negative impact on the economy's growth rate. The more recent literature goes a step further and asks how social capital, trust and the degree of acceptance of social norms can promote economic growth. It is evident that in explaining the determinants of these factors, the distribution of income and wealth has an important role to play.

\section{Inequality and the Accumulation of Human Capital}

However, the dominant explanation put forth in the recent literature is neither based on politico-economic nor on sociological explanations. This approach is based on the argument that imperfect capital markets may lead to severe efficiency losses when there is excessive inequality. For evident reasons, the accumulation of human capital plays a central role in explaining the growth process of modern economies.

The argument is simple: Education not only causes direct costs but is also a period without income. Individuals who lack the necessary funds and cannot raise these funds on the capital market have only limited access to the education system. Low-ability children of rich parents will get educated, whereas poor high-ability individuals will not, resulting in an inefficient allocation of talents.

The crucial point can be made in Figure 4. On the horizontal axis, we measure the level of human capital investment of a certain individual. The vertical axis shows the output level resulting from this investment. For simplicity, let us further assume that the relationship between investment and output is the same for all individuals (which means that all individuals are of equal ability).

Figure 4: Inequality and Human Capital Investment 
The optimal investment level equates the marginal return of an additional year of education to the interest rate. In Figure 4 this is the case at investment level $H^{*}$. When capital markets are imperfect, this may not be feasible for many individuals. The rich can invest the optimal amount $H^{*}$, whereas the amount of education that the poor can invest is lower, $H_{A}$. If the marginal returns are decreasing in the level of investment the wealth distribution affects the equilibrium outcome. The per-capita income of next period - the weighted average of $Y^{*}$ and $Y_{A}$ in Figure 4 - is lower, the larger the fraction of individuals for whom credit restriction become binding. Ceteris paribus, this fraction will be larger with a higher degree of inequality.

While capital market imperfections are certainly an argument that is of tremendous importance in developing countries, it is less clear how severe such capital market imperfections are in developed economies. Recent evidence by Cameron and Heckman (1999) suggests that educational outcomes are primarily determined by the social background - the family and the neighborhood in which an individual has grown up.

The truth lies most likely somewhere in between. In fact, a number of theoretical contributions, including Benabou (1996) and Durlauf (1996) demonstrate that if there are neighborhood effects in the accumulation of human capital (for instance, richer neighborhoods provide better schools) limited access to capital markets may lead to such segregation of the population by income thus reinforcing the importance of neighborhood effects. The economy ends up as a collection of communities across which there are high and persistent inequalities. Fershtman, Murphy and Weiss (1996) suggest further that status concerns associated with education may exacerbate such adverse inequality effects. Put in other terms, social background and imperfect capital markets are complementary rather than competing explanations. Whatever the particular channel, income inequality is a primary determinant of educational choices.

Do such theories help to explain U.S. and European differences in long-run productivity growth? First of all, it takes time for the process of human capital accumulation to manifest itself in productivity changes. The effects of inequality on educational choices are also longterm. A change in inequality today will have worked out its final effect not before the children of the youngest parents that are affected by the inequality change will have to make their education decision. Both observations suggest that we have to adopt a long-term perspective. In fact, we have seen that there are long-run differences in productivity growth 
between Europe and the U.S. Moreover, there are persistent differences in income inequality which most likely have widened recently.

Due to higher inequality, constraints in educational choices due to capital market imperfections are more severe in the U.S. than in Europe. Note also that such constraints are exacerbated by institutional differences in the education systems. In the U.S., education has comparably high private costs, in particular for higher education. The typical U.S. student has to pay high tuition fees. At primary and secondary education levels, the decreasing quality of U.S. public schools lead many richer parents to send their kids to (costly) private high schools - an option that is not available to poorer families. In contrast, in most European countries, access to university education is free (or cheap). While private schools are also widespread in some countries, lower European inequality implies that financing constraints may be less severe and widespread misallocation of talent is less likely. ${ }^{4}$

In sum, to the extent that better incentives for the accumulation of human capital are relevant for the superior (productivity) growth performance of Europe over the long run, lower income inequality may have contributed to that outcome.

\section{Imperfect Competition on Product Markets: Inequality and Innovation Incentives}

In the above models, the distribution of income and wealth affects the returns to accumulation and tomorrow's supply with factors of production. The demand for produced output plays a passive role. This is a convenient (while simplifying) assumption for many purposes. However, few economists would contradict the proposition that the expected level of demand for produced output is an important determinant of investment and innovation decisions. $^{5}$

\footnotetext{
${ }^{4}$ Results from the PISA-study of the OECD suggest that the performance of pupils in the U.S. corresponds to the average of other OECD countries. Moreover, there is evidence that the variance in student performance with respect to certain skills (in particular, literacy skills) have a higher variance in the U.S. than in most European countries. Note that this is in line with our reasoning: Despite higher per-capita incomes, education outcomes are not higher on average, and have a larger variance, than in lower-income and lower-inequality European countries.

${ }^{5}$ There are only few theoretical studies that have explored the implications the role of income distribution for the incentives to innovate. Among these, studies are Murphy, Shleifer and Vishny, (1989), Falkinger (1990, 1994)
} 
Income inequality comes into play, because consumer behavior is strongly determined by income. Consumers with different levels of income do not only spend different total amounts on consumption goods they also have a different structure of consumption. For instance, poor consumers will not only purchase (normal) goods in smaller quantity but will also purchase a different (smaller and lower quality) bundle of goods than the rich. ${ }^{6}$ As a consequence, the market demand for the various (in particular, new) products will depend on the income distribution. Hence income distribution may have an important effect on the incentives to innovate. To the extent that such innovations are a crucial source of technological progress, income distribution is a determinant of productivity growth.

To illustrate those mechanisms let us consider in more detail how income distribution affects the demand for new products: Suppose consumers have hierarchic preferences and concentrate their consumption expenditures on basic goods, before they start to buy conveniences and luxury goods. As a result, innovators will attract primarily rich buyers whereas poor consumers will not (immediately) be able to afford new goods. This leads to the presumption that a class of very rich people generates the necessary demand for new products. In fact, the idea that the consumption of luxury goods is an important engine of growth by creating new wants and maintaining incentives to provide effort also for the lower classes, is an argument which has already be stressed by the classical economists.

Can we argue that inequality is good for growth because it induces innovations? The answer is: not necessarily. The reason is that there is a trade-off between prices (which are high when a class of very rich people has a very high willingness to pay for new products) and market size (which will be low when incomes are strongly concentrated among a few rich). Moreover, what matters for innovators are not only profits today, but also how the market for the new product evolves in the future. Obviously, a more equal distribution of income is favorable in this respect. When there is a well-funded middle class market size rises quickly and fosters innovation incentives. In sum, it is a priori not clear whether positive price effects of high inequality outweigh the negative (static and dynamic) market size effects. Whether

and Chou and Talmain (1996), and Matsuyama (2002). For empirical evidence on the importance of nonhomothetic preferences, see Jackson (1984) and Falkinger and Zweimüller (1996).

${ }^{6}$ While this is an obvious point, it should be noted that existing macroeconomic models that deal with many products (to explain the process of innovations and growth) assume homothetic preferences. Under this assumption a consumer is half as rich as some other consumer purchases exactly half of the same goods as the richer consumer. As a result income distribution is irrelevant for market demand. 
inequality is good or bad for growth strongly depends on whether or not there exist close substitutes for the new goods. ${ }^{7}$

The above mechanism is the most obvious by which income distribution can affect innovations, but it is not the only one. Industrial $\mathrm{R} \& \mathrm{D}$ activities are to a large extent targeted towards better quality of existing products. ${ }^{8}$ With a very skewed income distribution, the rich have a high willingness to pay for luxurious products, and innovators may target predominantly goods that are purchased by the rich. In such a situation, less R\&D resources will be channeled into the improvement of mass production technologies. However, without substantial technological improvements in such mass consumption industries, that exploit economies of scale, productivity progress will be slow.

Furthermore, with a more even distribution of incomes, demand will be distributed more evenly across industries. This makes it easier for new methods of production to penetrate all industries in the economy. As a result, the dissemination of knowledge may be easier when there is a sizeable middle class.

These arguments may have played an important role to explain the exceptional catch-up that took place over the long run. During WWI and WWII the capital stock was destroyed and with it much of the sources of income inequality. In the $19^{\text {th }}$ century, European incomes were distributed less equally than in the U.S. Ironically, a number of economic historians have pointed to the importance of the rather egalitarian U.S. income distribution to explain the superior performance of the U.S. over the second half of the $19^{\text {th }}$ century. Abramovitz and David (2000) note

"In all the European countries, a traditional class structure - which separated a nobility and gentry form the peasantry, the tradesmen, and an expanding middle class - survived in the $19^{\text {th }}$ century. (...) Aristocratic standards of quality and individuality in consumption worked to inhibit the development of standardized goods and mass production, and they supported an extreme fragmentation of retail trade."

\footnotetext{
${ }^{7}$ If there are close substitutes for the innovators' products positive price effects of high inequality will not be strong, because innovators face higher competition form those close substitutes. In such a situation inequality is detrimental to innovation incentives (Zweimüller, 2000). If substitution possibilities are limited, the rich have a high willingness to pay for new products (Foellmi and Zweimüller, 2002) and price effects dominate the market size effects.

${ }^{8}$ See Zweimüller and Brunner, 1998, Li 1996, and Glass, 1996 for models where income distribution affects the incentive of innovators to introduce better quality of existing products.
} 
The dramatic recent changes in income distribution in the U.S. seem to have important implications for the structure of aggregate consumer demand. How this will affect the innovation incentives will, to a large extent, depend on how the new rich will spend their income. Will this stimulate innovations of completely new products and the invention of new technologies that can ultimately applied economy wide? Or are we back in a situation where the very rich (now those in the U.S.) use their income to satisfy the same "aristocratic standards of quality and individuality in consumption" that has hampered technological development in the Europe of the $19^{\text {th }}$ century? ${ }^{9}$ To the extent that a less egalitarian consumption structure leads to a lower potential for exploiting economies of scale and a slower dissemination of new technologies across all sectors, the increase in inequality may have detrimental effects on productivity growth in the future.

These are very important questions and they are equally hard to answer. So far, very little empirical research has been done about to role of inequality in determining the extent and types of innovations that are conducted in the economy. Among the few studies is Kremer (2002) who showed that income distribution and market size is of crucial importance in the pharmaceutical industry.

One might object that the above arguments are less important today as many firms operate on global markets. In that case, the global distribution of income rather than the distribution of income within countries matters. This is clearly the case for tradable goods. And to the extent that productivity growth is driven by innovations in those industries, the income distribution within countries is indeed less important.

However, there are a number of reasons why home markets matter even in the global economy. First of all, many products are non-tradable, in particular in the service sector. By definition, these products are produced and sold in the home market and their market demand will depend on the distribution of income within the home country. Second, if transportation costs are substantial, markets are segmented by geographical distance. In that case the geographical borders coincide to a large extent with national borders. Third, substantial legal trade barriers still exist. The mere fact that huge efforts have been undertaken to convince

\footnotetext{
${ }^{9}$ Frank (2000) and many others have pointed to the "luxury fever" and the dramatic changes in consumer behavior ("conspicuous consumption") that have been observed in the U.S. in recent decades.
} 
European citizens to remove these barriers Europe underlines their importance. Even if no such barriers existed within Europe (and within the U.S.) significant trade barriers exist across these areas. Hence the distribution within Europe as a whole within the U.S. as a whole (and less so the global distribution of income) matters for many producers. Fourth, the trade volume between Europe and the U.S. is relatively small compared to aggregate output of these economic areas. In other words, most production within Europe is sold within Europe, and the same is true for the U.S. Finally, even in a world with no trade barriers and transportation costs the home market may be important, simply because consumers' preferences are biased towards products of the own country.

\section{Conclusions}

In this paper we have looked at differences in macroeconomic outcomes between European countries and the U.S. and have discussed these differences in the context of income inequality.

Since the 1950s, Europe had the clearly better record in terms of productivity progress. By the mid 1990s many European countries have reached U.S. levels of productivity and some European countries are even more productive than the U.S. Since the mid 1990s, productivity growth in Europe lags somewhat behind the one of the U.S. but the recent (negative)

difference is small compared to the previous positive gap. Recent empirical evidence concerning income inequality suggests that inequality in the U.S. is considerably higher than in most European countries, and perhaps also higher than in Europe as a whole. Furthermore, the recent dramatic increase in U.S. top incomes suggests that the gap between Europe and the U.S. has dramatically widened along this dimension.

We have used arguments from the recent macroeconomic literature to interpret this empirical evidence. In particular, we were asking whether a even distribution of income is harmful or beneficial for productivity growth. While there are many potential channels by which income distribution might have affected, we have concentrated our discussion on two channels which seem to be of particular importance in modern economies: Human capital accumulation when there are imperfections in capital markets; and the effect of inequality on innovation incentives. 
This analysis suggests that lower income inequality in Europe may have contributed to larger productivity progress. Other things equal, less inequality implies less restrictions in the accumulation of human capital. To the extent that productivity growth is driven by the accumulation of human capital this may have been an advantage for Europe. Similar arguments can be made for innovation incentives. An income distribution that is less skewed towards top incomes may foster innovations and the adoption and dissemination of new technologies. 


\section{References}

Abramovitz, M. and P. David. (2000). American Macroeconomic Growth in the Era of Knowledge-Based Progress: The Long-Run Perspective, in: Engermann and Gallman (eds.) The Cambridge Economic History of the United States, CUP, pp.1-92.

Aghion, P. and P.Howitt. (1998). Endogenous Growth Theory. MIT-Press.

Aghion, P. and P. Bolton. (1997). “A Trickle-Down Theory of Growth and Development with Debt-Overhang," Review of Economic Studies 64, 151-172.

Alesina, A. and D. Rodrik. (1994). "Distributive Politics and Economic Growth," Quarterly Journal of Economics 109, 465-490.

Atkinson, A. (1995). Income Distribution in Europe and the U.S., Invited lecture at EALE Lyon, 1995.

Banerjee, A.V. and A. Newman. (1993). "Occupational Choice and the Process of Development," Journal of Political Economy 101, 274-298.

Benabou, R. (1996). “Inequality and Growth.” In B.S. Bernanke and J.J. Rotemberg (eds.), NBER Macroeconomics Annual 1996. Cambridge, MA: MIT Press.

Bertola, G. (2000). "Macroeconomics of Distribution and Growth.” In A. Atkinson and F. Bourguignon (eds.), Handbook of Income Distribution Chapter 9, Amsterdam: NorthHolland.

Blanchard, O. (2003). Macroeconomics, $3^{\text {rd }}$ edition, Prentice Hall.

Cameron S. and J. J. Heckman. (1998) "Life Cycle Schooling and Dynamic Selection Bias: Models and Evidence for Five Cohorts of American Males," Journal of Political Economy 106, 262-333.

Chou C.-F. and G. Talmain. (1996). "Redistribution and Growth: Pareto Improvements," Journal of Economic Growth 1, 505-523.

Durlauf, S. (1996). A Theory of Persistent Inequality, Journal of Economic Growth 1, 75-93. Engermann, S. L. and K. L. Sokoloff. (2002). Factor Endowments, Inequality, and Paths of Development among New World Economies, NBER Working Paper 9259.

Falkinger, J. (1990). “On Growth along a Hierarchy of Wants,” Metroeconomica 41, 209-223. Falkinger, J. (1994). “An Engelian Model of Growth and Innovation with Hierarchic Demand and Unequal Incomes," Ricerche Economiche 48, 123-139.

Falkinger, J. (1997). Wachstum, Verteilung und Beschäftigung, Working Paper 9712 , Universität Linz. 
Falkinger, J. and J. Zweimüller. (1996). "The Cross-country Engel-curve for Product Diversification," Structural Change and Economic Dynamics 7, 79-97.

Fersthman, Ch. Murphy, K.M. and Y. Weiss, (1996),. "Social Status, Education, and Growth," Journal of Political Economy 104, 108-132.

Foellmi, R. and J. Zweimüller. (2002). Heterogenous Mark-Ups, Demand Composition and the Inequality-Growth Relation, mimeo, University of Zurich.

Frank, R. (2000), Luxury Fever, The Free Press.

Galor O. and J. Zeira. (1993). "Income Distribution and Macroeconomics," Review of Economic Studies 60, 35-52.

Glass, A. J. (1996). "Income Distribution and Quality Improvement," mimeo, Ohio State University.

Gottschalk, P. and T. M. Smeeding. (2000). Empirical Evidence on Income Inequality in Industrial Countries, In A. Atkinson and F. Bourguignon (eds.), Handbook of Income Distribution, Chapter 5, Amsterdam: North- Holland.

Gordon, R. (2002). Two Centuries of Economic Growth: Europe Chasing the American Frontier, Paper prepared for Economic History Workshop, Northwestern University.

Jackson, L. F. (1984). "Hierarchic Demand the Engel-curve for Variety," Review of Economics and Statistics 66, 8-15.

Kremer, M. (2002). "Pharmaceuticals and the Developing World," Journal of Economic Perspectives 16, 67-90.

Li, C.-W. (1996). "Inequality and Growth: a Schumpeterian Perspective," mimeo, University of Glasgow.

Matsuyama, K. (2002). "The Rise of Mass Consumption Societies," Journal of Political Economy 110, 1035-1070.

Murphy, K. M., A. Shleifer, and R. Vishny. (1989). "Income Distribution, Market Size, and Industrialization," Quarterly Journal of Economics 104, 537-564.

Perotti, R. (1996). "Growth, Income Distribution and Democracy: What the Data Say," Journal of Economic Growth 1, 149-187.

Persson, T. and G.Tabellini. (1994). "Is Inequality Harmful for Growth?," American Economic Review 84, 600-621.

Piketty T. (2003). “Income Inequality in France 1901-1998,” Journal of Political Economy, forthcoming.

Piketty T. and E.Saez. (2003). "Income Inequality in the United States, 1913-1998," Quarterly Journal of Economics 108, 1-39. 
World Bank. (2003). World Development Report.

Zweimüller, J. and J.K. Brunner. (1998). "Innovation and Growth with Rich and Poor Consumers," CEPR Discussion Paper No. 1855, London.

Zweimüller, J. (2000). "Schumpeterian Entrepreneurs Meet Engel's Law: the Impact of Inequality on Innovation-Driven Growth," Journal of Economic Growth 5, 185-206. 
Figure 1: Trends in disposal income inequality Gini coefficients percentage change per year and absolute change per year: 1979 - 1995

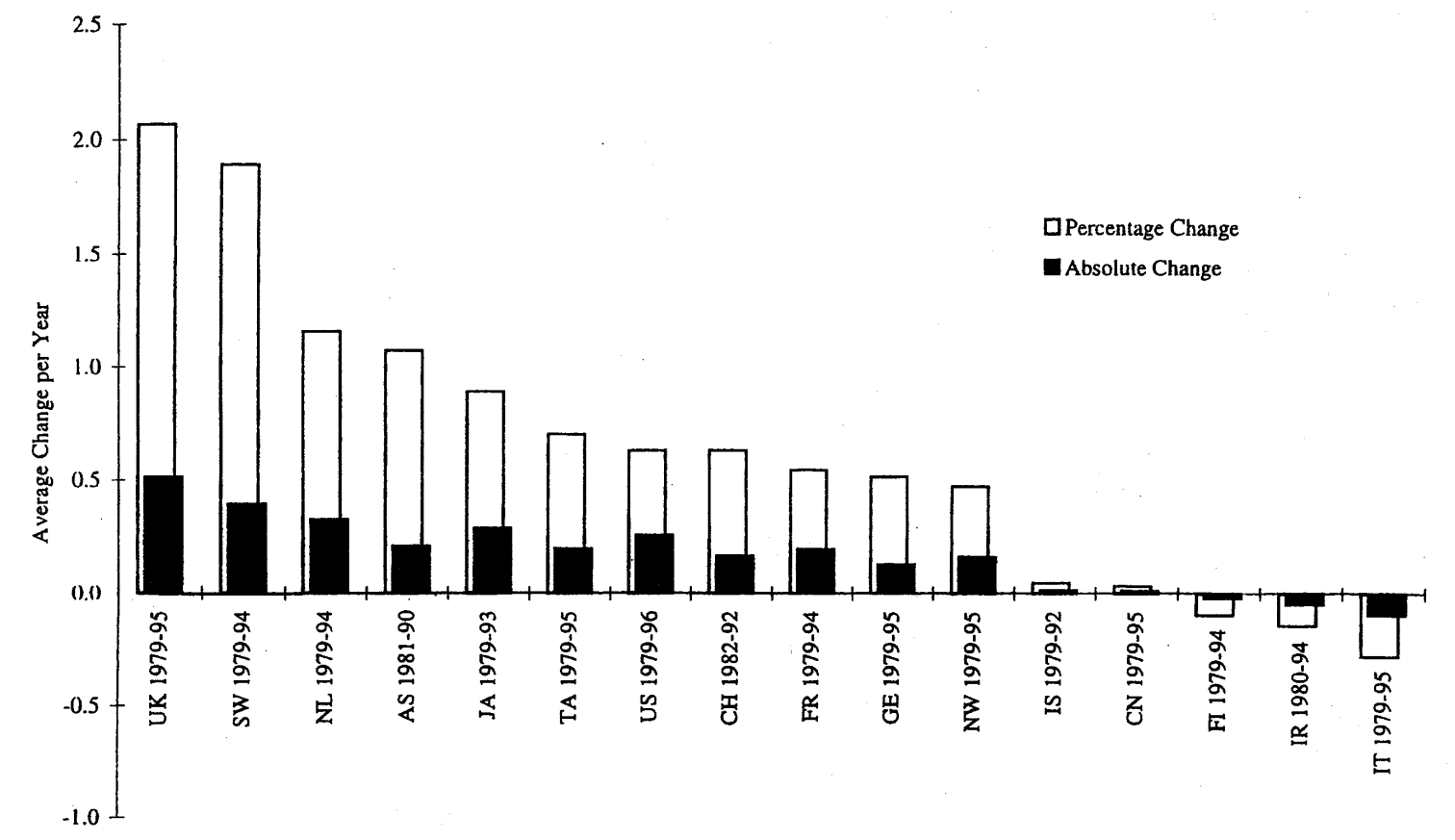

Source: Gottschalk and Smeeding (2000) 
Figure 2: Top $1 \%$ income shares, 1960 - 1998, France and USA

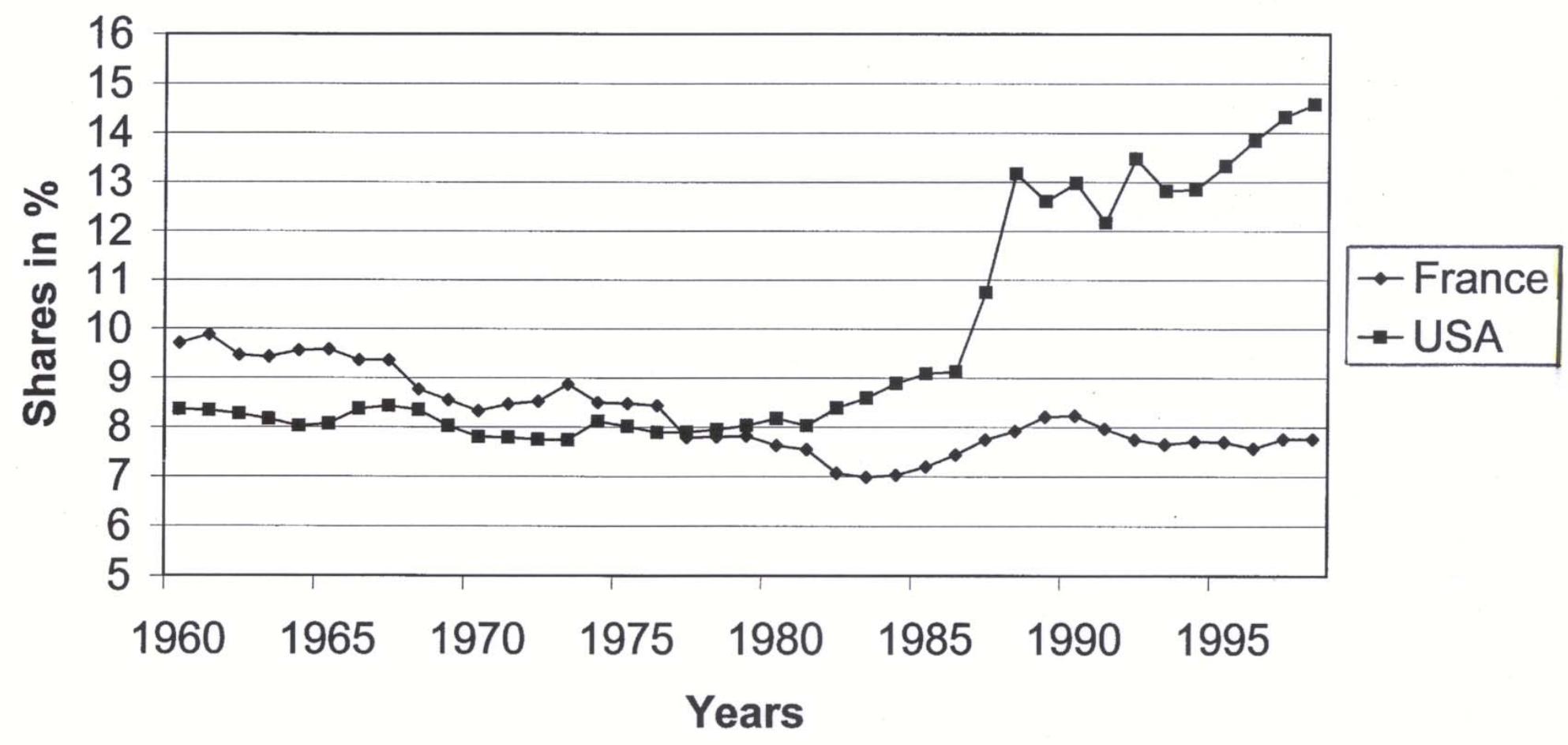


Figure 3: Real GDP per hour, Europe and USA, 1870 - 2000

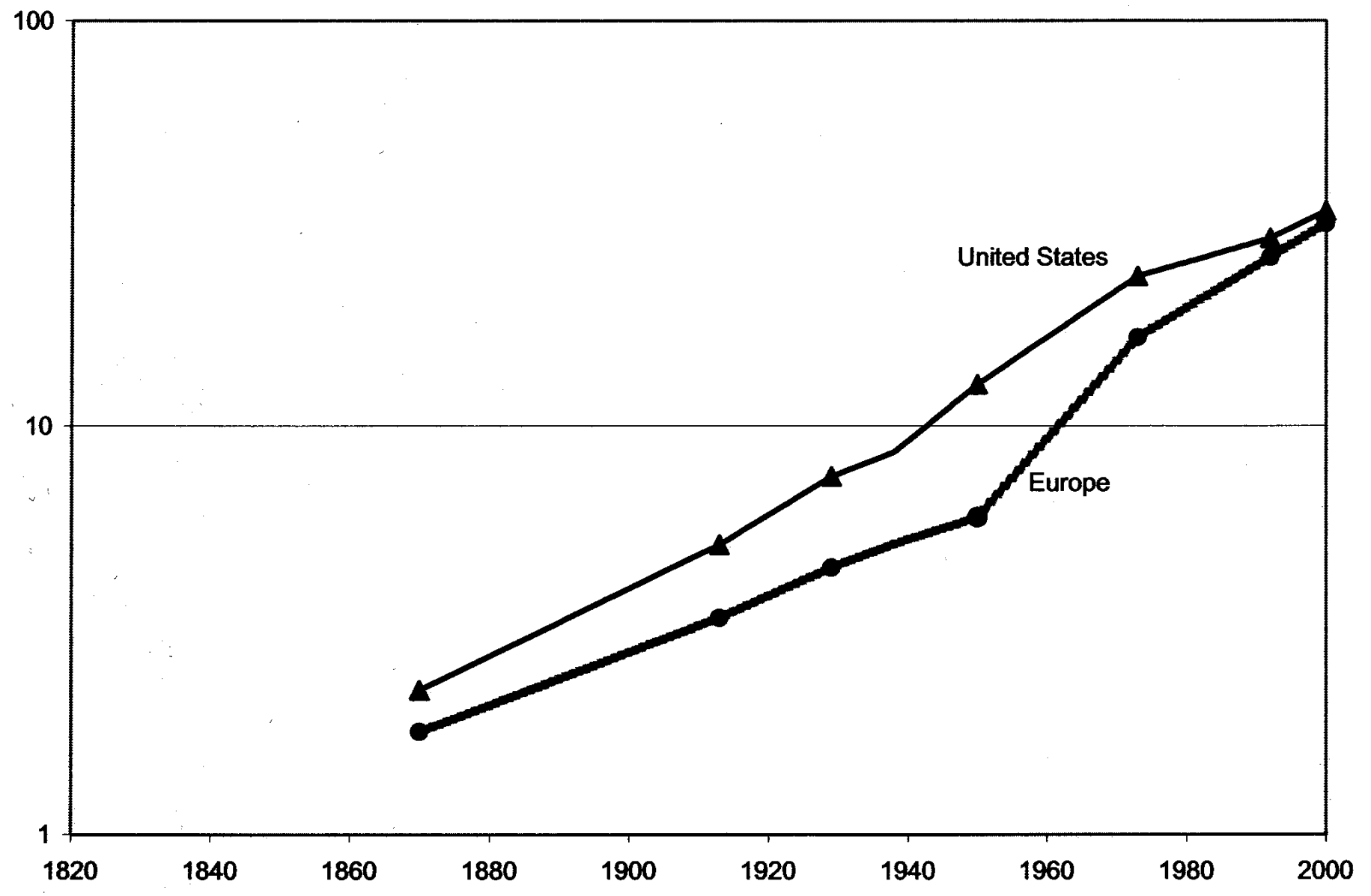

Source: Gordon (2002) 
Figure 4: Inequality and Human Capital Investment

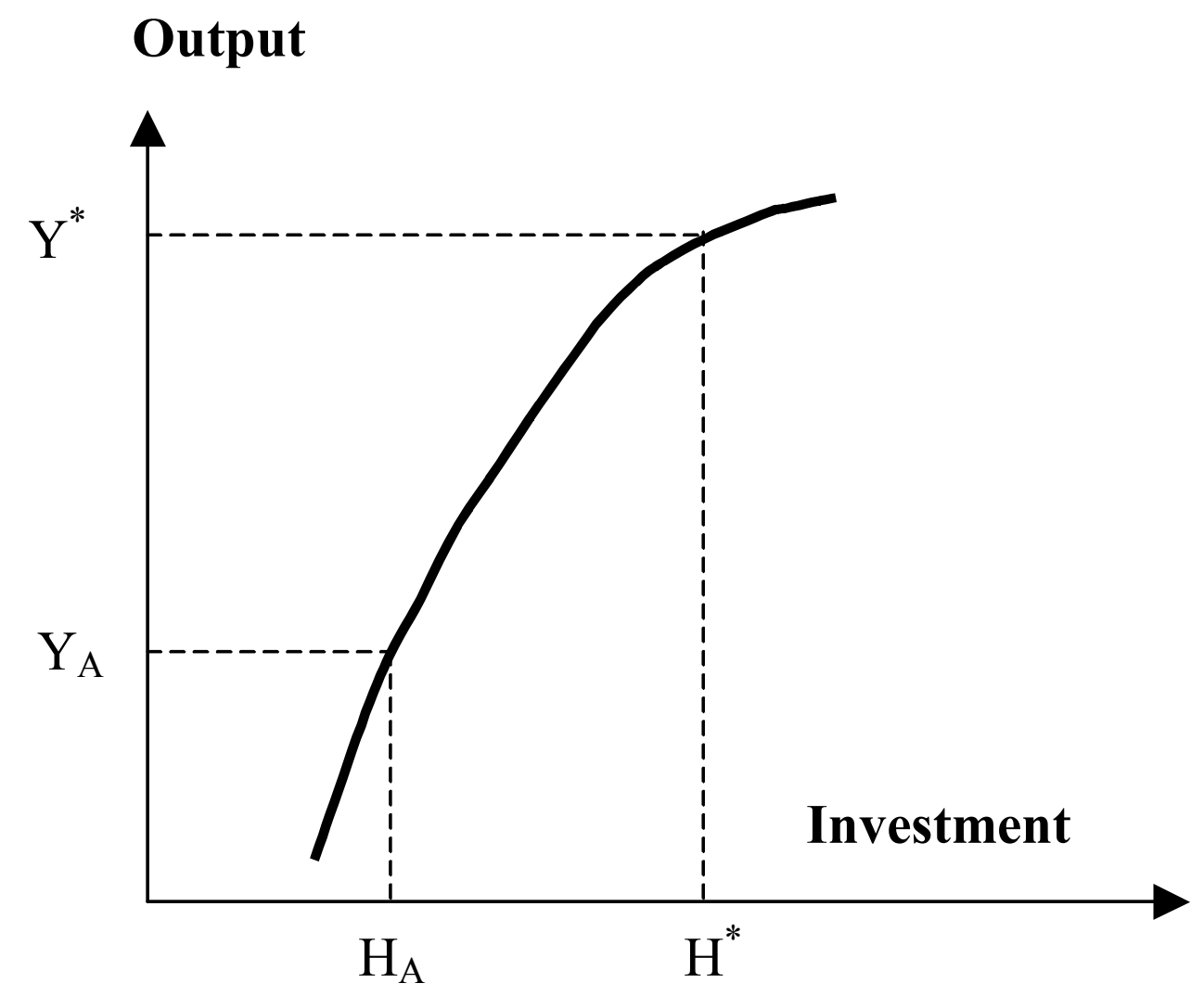


Table 1: Empirical evidence on income inequality in industrialized countries

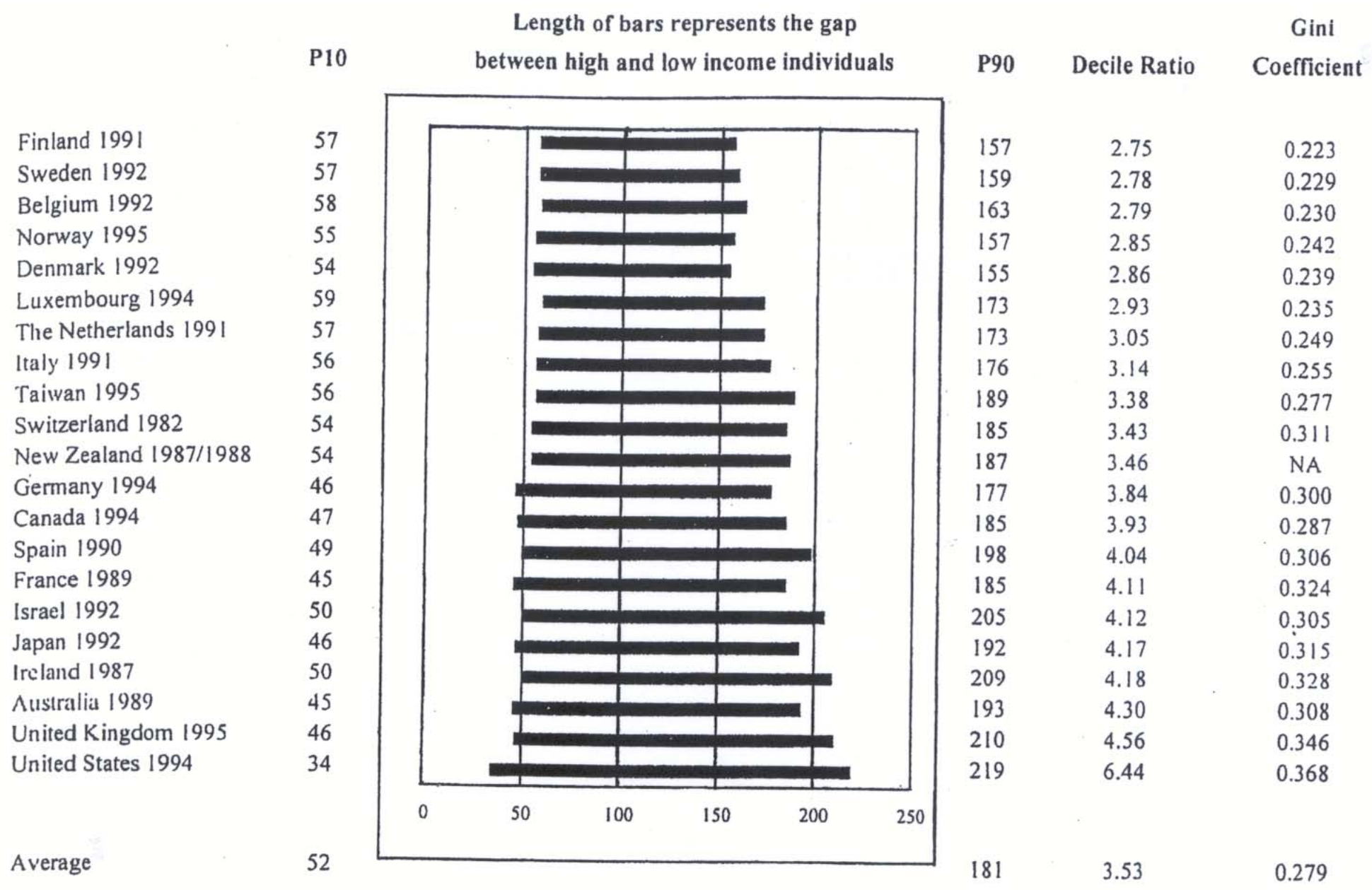

Source: Gottschalk and Smeeding (2000) 
Table 2: „Europe-wide“ and US distributions: shares of total income

\begin{tabular}{|l|ll|l|l|}
\hline $\begin{array}{l}\text { Share of decile } \\
\text { group }\end{array}$ & West Germany & Italy & United States & "Europe wide" \\
\hline 10 & 4.0 & 3.1 & 1.9 & 2.9 \\
20 & 9.8 & 8.0 & 5.7 & 7.9 \\
30 & 16.6 & 13.9 & 11.2 & 14.1 \\
40 & 24.2 & 20.7 & 18.0 & 21.3 \\
50 & 32.9 & 28.7 & 26.2 & 29.5 \\
60 & 42.5 & 38.0 & 35.7 & 39.0 \\
70 & 53.2 & 48.7 & 46.9 & 49.8 \\
80 & 65.3 & 61.2 & 60.2 & 62.3 \\
90 & 79.4 & 76.2 & 76.3 & 77.2 \\
\hline
\end{tabular}

Source: Atkinson (1995) 


\section{Working Papers of the Institute for Empirical Research in Economics}

No.

120 Ernst Fehr, Urs Fischbacher and Elena Tougareva: Do High Stakes and Competition Undermine Fairness? Evidence from Russia, July 2002

121 Enrico De Giorgi: Reward-Risk Portfolio Selection and Stochastic Dominance, August 2002

122 Enrico De Giorgi: A Note on Portfolio Selections under Various Risk Measures, August 2002

123 Klaus Reiner Schenk-Hoppé: Resuscitating the Cobweb Cycle, July 2002

124 Alois Stutzer: The Role of Income Aspirations in Individual Happiness, August 2002

125 Ernst Fehr and Lorenz Götte: Do Workers Work More if Wages are High? Evidence from a Randomized Field Experiment, July 2002

126 Anke Gerber, Thorsten Hens and Bodo Vogt: Rational Investor Sentiment, December 2002

127 Matthias Benz and Alois Stutzer: Do Workers Enjoy Procedural Utility?, September 2002

128 Thorsten Hens, Klaus Reiner Schenk-Hoppé and Martin Stalder: An Application of Evolutionary Finance to Firms Listed in the Swiss Market Index, August 2002

129 Bruno S. Frey, Matthias Benz and Alois Stutzer: Introducing Procedural Utility: Not only What, but also How Matters, October 2002

130 Ernst Fehr and Jean-Robert Tyran: Limited Rationality and Strategic Interaction, The Impact of the Strategic Environment on Nominal Inertia, November 2002

131 Armin Falk, Rafael Lalive and Josef Zweimüller: The Sucess of Job Applications: A New Approach to Program Evaluation, November 2002

132 Dirk Engelmann and Urs Fischbacher: Indirect Reciprocity and Strategic Reputation, Building in an Experimental Helping Game, November 2002

133 U. Fischbacher, Christina M. Fong and Ernst Fehr: Fairness and the Power of Competition, January 2003

134 E. Fehr and John A. List: The Hidden Costs and Returns of Incentives - Trust and Trustworthiness among CEOs, November 2002

135 Bruno S. Frey and Matthias Benz: Being Independent is a Great Thing: Subjective Evaluations of SelfEmployment and Hierarchy, May 2003, REVISED VERSION

136 Bruno S. Frey and Simon Luechinger: Terrorism: Deterrence May Backfire, December 2002

137 Bruno S. Frey and Simon Luechinger: How To Fight Terrorism: Alternatives To Deterrence, December 2002

138 Thorsten Hens and Bodo Vogt: Money and Reciprocity, December 2002

139 Thorsten Hens and Klaus Reiner Schenk-Hoppé: Markets Do Not Select For a Liquidity Preference as Behavior Towards Risk, December 2002

140 Ernst Fehr and Joseph Henrich: Is Strong Reciprocity a Maladaptation? On the Evolutionary Foundations of Human Altruism, January 2003

141 Ernst Fehr, Urs Fischbacher, Bernhard von Rosenbladt, Jürgen Schupp and Gert G. Wagner: A Nation-Wide Laboratory Examining trust and trustworthiness by integrating behavioral experiments into representative surveys, January 2003

142 Reto Foellmi, Manuel Oechslin: Who Gains From Non-Collusive Corruption?, January 2003

143 Alois Stutzer and Bruno S. Frey: Does Marriage Make People Happy, Or Do Happy People Get Married?, January 2003

144 Armin Falk and Andrea Ichino: Clean Evidence on Peer Pressure, January 2003

145 Reto Foellmi, Josef Zweimueller: Inequality, Market Power, and Product Diversity, March 2003

146 Armin Falk and Michael Kosfeld: It's all about Connections: Evidence on Network Formation, March 2003

147 Bruno S. Frey and Alois Stutzer: Testing Theories of Happiness, April 2003

148 Bruno S. Frey and Stephan Meier: Do Business Students Make Good Citizens?, May 2003

149 Bruno S. Frey and Stephan Meier: The Economics of Museums, May 2003

150 Armin Falk, Urs Fischbacher and Simon Gächter: Living in Two Neighborhoods - Social Interactions in the Lab, May 2003

151 Alois Stutzer and Bruno S. Frey: Stress That Doesn't Pay: The Commuting Paradox, June 2003

152 Michael Kosfeld: Network Experiments, May 2003

153 Aleksander Berentsen, Esther Brügger and Simon Lörtscher: On Cheating and Whistle-Blowing, June 2003

The Working Papers of the Institute for Empirical Research in Economics can be downloaded in PDF-format from http://www.iew.unizh.ch/wp 


\section{Working Papers of the Institute for Empirical Research in Economics}

No.

154 Aleksander Berentsen, Guillaume Rocheteau and Shouyong Shi: Friedman meets Hosios: Efficiency in Search Models of Money, June 2003

155 Aleksander Berentsen and Guillaume Rocheteau: On the Friedman Rule in Search Models with Divisible Money, June 2003

156 Aleksander Berentsen: Time-Consistent Private Supplie of Outside Paper Money, June 2003

157 Haim Levy, Enrico De Giorgi and Thorsten Hens: Prospect Theory and the CAPM: A contradiction or coexistence? June 2003

158 Reto Foellmi and Josef Zweimüller: Inequality and Economic Growth - European Versus U.S. Experiences, June 2003

The Working Papers of the Institute for Empirical Research in Economics can be downloaded in PDF-format from http://www.iew.unizh.ch/wp/

Institute for Empirical Research in Economics, Blümlisalpstr. 10, 8006 Zürich, Switzerland

Phone: 004116343705 Fax:0041 16344907 E-mail: bibiewzh@,iew.unizh.ch 